\title{
Evaluation for Released and Promising Genotypes of Potato against Red Ant
}

\author{
Prem Nidhi Sharma ${ }^{1}$, Ram Chandra Adhikari ${ }^{2}$, Bhim Bahadur Khatri ${ }^{2}$, and Kalika Prasad Upadhyay ${ }^{2}$ \\ 1Entomology Division, NARC, Khumaltar, Lalitpur, Nepal; @: premnidhi@yahoo.com, \\ ORCID:https://orcid.org/0000-0001-5647-9258 \\ ${ }^{2}$ National Potato Research Program, NARC, Khumaltar, Lalitpur, Nepal; RCA: rcadhikari7@ gmail.com; \\ BBK:bhim_khatri@hotmail.com>; KPU: kalikaupadhyay@yahoo.com>
}

Received 7 Jan 2019, Revised 12 Feb 2019, Accepted 25 Feb 2019, Published 28 April 2019

Scientific Editors: Subash Subedi, Krishna Timsina

Copyright $(0) 2019$ NARC. Permits unrestricted use, distribution and reproduction in any medium provided the original work is properly cited.

The authors declare that there is no conflict of interest.

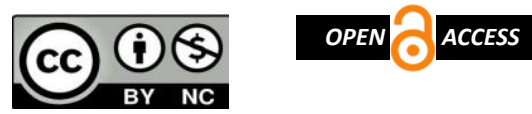

Licensed under the Creative Commons AttributionNonCommercial 4.0 International (CC BY-NC 4.0)

\begin{abstract}
Red ant is the most destructive insect pest of potato tubers in the field. Utilization of varietal resistance is the best option to control the pest. The resistance of five released and nine promising genotypes of potato were evaluated against red ant (Dorylus orientalis Westwood) under natural infestation in red ant prone field. Potato resistance was evaluated based on tuber damage index value (0.00 to 1) which was calculated on the bases of the percentage of damaged tubers and number of injuries on per kilogram of tubers made by the pest. Based on the results of combined data, the levels of varietal damage were categorized to be less damaged (TDI value ranging from 0.35 to 0.49 ), moderately damaged (TDI value ranging from 0.50 to 0.64 ) and highly damaged (TDI value ranging from 0.65 to 0.79 ) types. Among the 14 genotypes compared for levels of tuber damage, the five genotypes: IPY-8 (TDI value: 0.35), Khumal Seto (TDI value: 0.39), PRP-056267.1 (TDI value: 0.40), Janak Dev (TDI value: 0.44) and PRP-25861.1 (TDI value: 0.49) were determined to be the less damaged types. The less damaged potato genotypes can be used by farmers as the relatively resistant genotypes against red ant.
\end{abstract}

Keywords: Red ant, Dorylus orientalis, Potato, Varietal resistance, Varietal damage evaluation

\section{सारांश}

रातो कमिला खेतबारीमा आलुको दानालाई सबैभन्दा बढ़ क्षेती गर्ने किरा हो। रातो कमिलाले कम खाने आलुको जातको प्रयोग गर्नु नै यो किराको नियन्त्रणको उत्तम बिकल्प हो। आलुका $१ \curlyvee$ वटा उन्मोचित तथा उत्कृष्ट लाईनका जातलाई रातो कमिलाले ग्रसित खेतबारीमा रातो कमिला बिरुध्द आलुको जातिय परिक्षण गरिएको थियो । रातो कमिलाले आलुको दानामा पार्ने क्षतिको आधारमा आलुलाई कम, मध्यम र बढी खाने जातमा वर्गिकरण गरिएको थियो। रातो कमिलाले आलुको दानामा पार्ने क्षतिलाई ट्युबर ड्यामेज इन्डेक्स (टिडीआई) मान ( 0.00 देखि १) ले मापन गरिएको थियो । परिक्षणका नतिजालाई गाभी बिश्लेसण गर्दा टिडीआई मान $०$.३้ देखि $० . ४ ९$ सम्म भएका जातलाई कम खाने, $०$. ५० देखि ०.६४ सम्म भएका जातलाई मध्यम खाने र ०.६५ देखि $० . ७ ९$ सम्म भएका जातलाई बढी खाने जातमा बर्गिकरण गरिएको थियो। परिक्षण बाट प्राप्त नतिजा अनुसार आलुका निम्न $y$ जात :आइपीवाइ $क($ टिडीआइमान:०.३२), खुमल सेतो (टिडीआइमान:०.३९), पीआरपी ०५६२६७.१(टिडीआइमान:०.४०), जनकदेब (टिडीआइ मान:०. ४૪) र पीआरपी २४६६१११(टिडीआइमान:०. ४९)लाई रातो कमिलाले कम क्षती गरेको हुँदा यी जातलाई रातो कमिला बिरुद्ध तुलनात्मक रुपमा कम खाने जातमा बर्गिकरण गरियो। उक्त जातहरुलाई कृषकहरुले रातो कमिलाले कम खाने आलुका जातका रुपमा प्रयोग गर्न सक्छे।

\section{INTRODUCTION}

Potato (Solanum tuberosum L) is daily used vegetable commodity and an important source of carbohydrate after rice, maize, and wheat in Nepal. It is considered a non-cereal food crop and is important source of income for subsistence farmers in Nepal. Potato is cultivated throughout the country, however, widely produced in the middle and high hills region of Nepal. Insect pests are the major biotic 
constraints to reduce potato yield in Nepal. Among the several major insect pests of potato, red ant (Dorylus orientalis Westwood) is the most destructive one to damage the potato tubers in the field. Past studies showed that this pest is more severe particularly in the middle and high hills region of Nepal (Joshi 1998). Previous studies conducted in the various parts of Nepal showed that it caused 15 to $82 \%$ tuber damage in potato fields (Joshi 1998, Pandey and Dhital 1995, Bhandari 2011, RARS 2011/12). In India and Bangladesh, 35 to $90 \%$ damage of potato tubers by this pest was reported (Mishra et al 1993, Konor etal 2005, Alam 2012).Utilization of host plant resistance, the basic component of integrated pest management (IPM), is one of the option to minimize crop losses caused by the pests (Sharma et al 2003a, 2003b, 2004, 2005, 2010, 2012a, 2012b, 2014). Earlier studies had identified some local varieties of potato such as Sabet local, Chisapani Rato and Khumbule to be least damaged by red ants in Lumle, Bhitri, and Kabre in Nepal (Joshi 1998). Few studies were conducted recently on varietal resistance of potato against red ant in Nepal (Sharma et al 2015). The studies showed that the potato genotypes CIP385499.11, CIP-393077.54, PRP-056267.9, PRP-056267.1, CIP-395112.32, and PRP-016567.12 were found the least damaged types. The main objective of this study is to provide the comparison of resistance of fourteen released and promising genotypes of potato against a red ant.

\section{MATERIALS AND METHODS}

Fourteen released and promising genotypes of potato were obtained from the National Potato Research Program (NPRP), Nepal Agricultural Research Council (NARC), Khumaltar, Lalitpur for screening resistance against red ant (Dorylus orientalis Westwood). The potato genotypes were grown three times in two different seasons at two different locations in red ant prone field under natural infestation condition (February planting at Boch, Dolakha during 2014/2015; October and February planting at Khumaltar, Lalitpur during 2014/2015). The Boch is located at high hills region, and Khumaltar is located at mid hills region of Nepal with the altitude of $2165 \mathrm{~m}$ and $1300 \mathrm{~m}$, respectively. The varieties were grown in three replications in a randomized complete block design. The agronomical practices were followed as per the NPRP recommendation. Each plot was a single row of $2.5 \mathrm{~m} \mathrm{x} 0.6 \mathrm{~m}$ where 10 plants of a genotype were planted. The spacing between the plants was $25 \mathrm{~cm}$ and between the rows was $60 \mathrm{~cm}$. Fertilizer was applied at the rate of 100:100:60 NPK plus 20t FYM/ha. To compare varietal resistance of the test genotypes, at first the three data (of two different seasons and locations) were separately analyzed. Then all the three data were combined into one to achieve a conclusive result for final determination of a level of tubers damage for the test genotypes. Varietal resistance was evaluated based on the varietal damage caused by red ant. Varietal damage was measured based on the Tubers Damage Index (TDI) value (0.00 to 1) which was calculated based on the percentage of damaged tubers and number of injured holes on per kilogram of tubers of a genotype. Lower the TDI value of a genotype higher is the resistance of the genotype. A formula developed by Sharma et al (2015) was used to calculate the TDI value. The TDI value of a genotype $=\{$ Percentage of damaged tubers (a) + Number of injuries on per kilogram of tubers (b) $\}$ / the highest value of a sum of (a) and (b) of the same replication. The levels of varietal damage (varietal resistance) of the test genotypes were determined based on the conclusive result of the combined data. Based on the ranges of TDI value (0.35 to 0.79$)$ of the combined data, the potato genotypes were categorized into less damaged (0.35 to 0.49$)$, moderately damaged ( 0.50 to 0.64$)$ and highly damaged (0.65 to 0.79$)$ types. The whole range of TDI values $(0.35$ to 0.79$)$ was divided into 3 equal ranges $(0.35$ to 0.49$),(0.50$ to 0.64$)$ and (0.65 to 0.79$)$ to determine less damaged, moderately damaged and highly damaged genotypes. The data was analyzed using GenStat5.

\section{RESULTS}

At first, the levels of tubers damage of 14 genotypes of potato were evaluated separately using the three individual data obtained from two different seasons and locations (Table1, Table2 and Table3). The final determination of levels of tubers damage of 14 genotypes was performed based on the combined analysis of the three data (Table4). The three separate data shown in Table1, Table 2 and Table 3 showed more or less similar results for the levels of tuber damage of the test genotypes. 
Table1. Damage level of tubers of potato genotypes caused by red ant (Dorylus orientalis), planted at Boch, Dolakha during February 2015

\begin{tabular}{llllllll}
\hline SN & Genotype & $\begin{array}{l}\text { Number of } \\
\text { tubers }\end{array}$ & $\begin{array}{l}\text { Weight of } \\
\text { tubers }(\mathbf{k g})\end{array}$ & $\begin{array}{l}\text { \%of } \\
\text { damaged } \\
\text { tubers }\end{array}$ & $\begin{array}{l}\text { Insect } \\
\text { injuries } \\
\text { /kg tubers }\end{array}$ & $\begin{array}{l}\text { TDI } \\
\text { value }\end{array}$ & $\begin{array}{l}\text { Level of } \\
\text { tubers } \\
\text { damage }\end{array}$ \\
\hline 1 & Khumal Seto & 53.7 & 1.458 & 36.9 & 25.1 & 0.27 & LD \\
\hline 2 & PRP-056267.1 & 56.7 & 1.188 & 41.9 & 34.6 & 0.36 & LD \\
\hline 3 & CIP-394050.110 & 99 & 2.650 & 60.7 & 38.6 & 0.42 & LD \\
\hline 4 & IPY-8 & 67 & 1.780 & 40 & 23 & 0.29 & LD \\
\hline 5 & NPI-106 & 66.7 & 1.667 & 70.6 & 47.5 & 0.54 & MD \\
\hline 6 & CIP-395112.32 & 32.3 & 0.583 & 75.7 & 109.3 & 0.77 & HD \\
\hline 7 & Desiree & 14 & 0.180 & 65 & 120 & 0.82 & HD \\
\hline 8 & Cardinal & 63.3 & 1.487 & 87.6 & 112.8 & 0.88 & HD \\
\hline 9 & PRP-85861.8 & 64.3 & 1.980 & 33.8 & 17.4 & 0.24 & LD \\
\hline 10 & PRP-25861.1 & 55.7 & 1.633 & 51.9 & 34.2 & 0.40 & LD \\
\hline 11 & PRP-226567.11 & 170.3 & 3.527 & 52.6 & 47.6 & 0.44 & LD \\
\hline 12 & CIP-385499.11 & 74.3 & 2.393 & 79.3 & 50.7 & 0.59 & MD \\
\hline 13 & Janak Dev & 88.3 & 2.733 & 42.6 & 22.5 & 0.25 & LD \\
\hline 14 & Kufri Jyoti & 30.3 & 0.793 & 59.1 & 52.9 & 0.53 & MD \\
\hline & GM & 66.9 & 1.718 & 57 & 52.6 & 0.48 & \\
\hline & F-test & $* *$ & $* *$ & $*$ & $* *$ & $* *$ & \\
\hline & LSD $(0.05)$ & 31 & 0.778 & 33.2 & 47.7 & 0.29 & \\
\hline & CV\% & 27.6 & 27 & 34.7 & 54 & 36.5 & \\
\hline
\end{tabular}

Note: TDI: Tubers Damage Index, LD: Less damaged genotype, MD: Moderately damaged genotype, and HD: Highly damaged genotype

Table2. Damage level of tubers of potato genotypes caused by red ant (Dorylus orientalis) planted at Khumaltar, Lalitpur during October 2014

\begin{tabular}{llllllll}
\hline SN & Genotype & $\begin{array}{l}\text { Number of } \\
\text { tubers }\end{array}$ & $\begin{array}{l}\text { Weight of } \\
\text { tubers }(\mathbf{k g})\end{array}$ & $\begin{array}{l}\text { \% of } \\
\text { damaged } \\
\text { tubers }\end{array}$ & $\begin{array}{l}\text { Insect } \\
\text { injuries } / \mathbf{k g} \\
\text { tubers }\end{array}$ & TDI value & $\begin{array}{l}\text { Level of } \\
\text { tubers } \\
\text { damage }\end{array}$ \\
\hline 1 & Khumal Seto & 64.7 & 1.712 & 74 & 72.4 & 0.54 & LD \\
\hline 2 & PRP-056267.1 & 86 & 2.250 & 53.1 & 55 & 0.38 & LD \\
\hline 3 & CIP-394050.110 & 123 & 1.651 & 74.1 & 131 & 0.73 & MD \\
\hline 4 & IPY-8 & 89.7 & 1.672 & 53.4 & 62.8 & 0.43 & LD \\
\hline 5 & NPI-106 & 58.7 & 0.828 & 64.8 & 111.9 & 0.64 & MD \\
\hline 6 & CIP-395112.32 & 46.3 & 0.911 & 58.5 & 118.5 & 0.64 & MD \\
\hline 7 & Desiree & 44.7 & 0.846 & 58.8 & 119 & 0.63 & MD \\
\hline 8 & Cardinal & 64.3 & 1.253 & 65.1 & 124.9 & 0.70 & MD \\
\hline 9 & PRP-85861.8 & 73.3 & 1.051 & 72.9 & 173.8 & 0.90 & HD \\
\hline 10 & PRP-25861.1 & 93.7 & 2.451 & 67.8 & 63 & 0.48 & LD \\
\hline 11 & PRP-226567.11 & 139.7 & 3.668 & 76.3 & 88.9 & 0.61 & MD \\
\hline 12 & CIP-385499.11 & 78 & 1.881 & 72.5 & 75.9 & 0.54 & LD \\
\hline 13 & Janak Dev & 100.7 & 2.070 & 75.3 & 80.5 & 0.58 & MD \\
\hline 14 & Kufri Jyoti & 83 & 1.920 & 70.8 & 96.4 & 0.60 & MD \\
\hline & GM & 81.8 & 1.710 & 67 & 98.2 & 0.60 & \\
\hline & F-test & $* *$ & $* *$ & $n s$ & $*$ & $*$ & \\
\hline & LSD $(0.05)$ & 45.6 & 1.109 & 28.46 & 69.46 & 0.33 & \\
\hline & CV\% & 33.2 & 38.3 & 25.3 & 42.2 & 0.33 & \\
\hline
\end{tabular}

Note: TDI: Tubers Damage Index,LD: Less damaged genotype, MD: Moderately damaged genotype, and HD: Highly damaged genotype 
Table 3. Damage level of tubers of potato genotypes caused by red ant (Dorylus orientalis), planted at Khumaltar, Lalitpur during February 2015

\begin{tabular}{llllllll}
\hline SN & Genotype & $\begin{array}{l}\text { Number of } \\
\text { tubers }\end{array}$ & $\begin{array}{l}\text { Weight of } \\
\text { tubers }(\mathbf{k g})\end{array}$ & $\begin{array}{l}\text { \% of } \\
\text { damaged } \\
\text { tubers }\end{array}$ & $\begin{array}{l}\text { Insect } \\
\text { injuries } / \mathbf{k g} \\
\text { tubers }\end{array}$ & $\begin{array}{l}\text { TDI value } \\
\text { Level of } \\
\text { tubers } \\
\text { damage }\end{array}$ \\
\hline 1 & Khumal Seto & 28 & 0.820 & 44.9 & 38.7 & 0.36 & LD \\
\hline 2 & PRP-056267.1 & 95.3 & 2.077 & 47.2 & 58.4 & 0.45 & LD \\
\hline 3 & CIP-394050.110 & 58.3 & 1.107 & 52.1 & 78.4 & 0.56 & MD \\
\hline 4 & IPY-8 & 40.3 & 0.967 & 41.3 & 33.4 & 0.32 & LD \\
\hline 5 & NPI-106 & 67 & 1.513 & 72.2 & 79.3 & 0.63 & MD \\
\hline 6 & CIP-395112.32 & 11.3 & 0.127 & 66.1 & 137.2 & 0.85 & HD \\
\hline 7 & Desiree & 34.3 & 1.147 & 71.9 & 72.2 & 0.61 & MD \\
\hline 8 & Cardinal & 31.7 & 0.800 & 73.2 & 113.7 & 0.79 & HD \\
\hline 9 & PRP-85861.8 & 45 & 1.273 & 74.3 & 85.2 & 0.67 & MD \\
\hline 10 & PRP-25861.1 & 35 & 1.053 & 74.6 & 65 & 0.59 & MD \\
\hline 11 & PRP-226567.11 & 100 & 1.827 & 61.2 & 85.3 & 0.63 & MD \\
\hline 12 & CIP-385499.11 & 45.7 & 1.717 & 58.4 & 35.5 & 0.41 & LD \\
\hline 13 & Janak Dev & 48.3 & 1.347 & 58 & 59.2 & 0.49 & MD \\
\hline 14 & Kufri Jyoti & 41 & 1.413 & 59.1 & 44.7 & 0.45 & LD \\
\hline & GM & 48.7 & 1.228 & 61 & 70.4 & 0.56 & \\
\hline & F-test & $* *$ & $*$ & $*$ & $* *$ & $*$ & \\
\hline & LSD $(0.05)$ & 38 & 1.03 & 27.4 & 48.3 & 0.28 & \\
\hline & CV\% & 46.6 & 49.8 & 26.8 & 40.9 & 29.9 & \\
\hline Note:TDI: Tubers Damage Index,LD: Less damaged genotype, MD: Moderately damaged genotype, and HD: Highly damaged \\
genotype
\end{tabular}

Table 4. Combined analysis of the level of tubers damage of potato genotypes caused by red ant (Dorylus orientalis) planted at different locations and seasons during 2014 and 2015

\begin{tabular}{llcccccc}
\hline SN & Genotype & $\begin{array}{l}\text { Number } \\
\text { of tubers }\end{array}$ & $\begin{array}{l}\text { Weight of } \\
\text { tubers }(\mathbf{k g})\end{array}$ & $\begin{array}{l}\text { \% of } \\
\text { damaged } \\
\text { tubers }\end{array}$ & $\begin{array}{l}\text { Insect } \\
\text { injuries /kg } \\
\text { tubers }\end{array}$ & TDI value & $\begin{array}{l}\text { Level of } \\
\text { tubers } \\
\text { damage }\end{array}$ \\
\hline 1 & Khumal Seto & 48.8 & 1.330 & 51.9 & 45.4 & 0.39 & LD \\
\hline 2 & PRP-056267.1 & 79.3 & 1.838 & 47.4 & 49.4 & 0.40 & LD \\
\hline 3 & CIP-394050.110 & 93.4 & 1.802 & 62.3 & 82.7 & 0.57 & MD \\
\hline 4 & IPY-8 & 65.7 & 1.473 & 44.9 & 39.8 & 0.35 & LD \\
\hline 5 & NPI-106 & 64.1 & 1.336 & 69.2 & 79.6 & 0.61 & MD \\
\hline 6 & CIP-395112.32 & 30.0 & 0.540 & 66.8 & 122 & 0.75 & HD \\
\hline 7 & Desiree & 31.0 & 0.724 & 65.2 & 104 & 0.69 & HD \\
\hline 8 & Cardinal & 53.1 & 1.180 & 75.3 & 117 & 0.79 & HD \\
\hline 9 & PRP-85861.8 & 60.9 & 1.435 & 60.4 & 92.1 & 0.61 & MD \\
\hline 10 & PRP-25861.1 & 61.4 & 1.713 & 64.8 & 54.1 & 0.49 & LD \\
\hline 11 & PRP-226567.11 & 137 & 3.007 & 63.4 & 74.0 & 0.56 & MD \\
\hline 12 & CIP-385499.11 & 66.0 & 1.997 & 70.1 & 54.0 & 0.51 & MD \\
\hline 13 & Janak Dev & 79.1 & 2.050 & 58.6 & 54.1 & 0.44 & LD \\
\hline 14 & Kufri Jyoti & 51.4 & 1.376 & 63.0 & 64.6 & 0.53 & MD \\
\hline & GM & 65.8 & 1.557 & 61.7 & 73.7 & 0.55 & \\
\hline & F-test & $* *$ & $*$ & $*$ & $* *$ & $* *$ & \\
\hline & LSD $(0.05)$ & 18.02 & 0.468 & 15.04 & 33.5 & 0.17 & \\
\hline & CV\% & 16.3 & 17.9 & 14.5 & 27.1 & 18.7 & \\
\hline
\end{tabular}

Note: TDI: Tubers Damage Index; Lower the TDI value of a genotype higher the resistance of the genotype. LD: Less damaged genotype, MD: Moderately damaged genotype, and HD: Highly damaged genotype 
The levels of tuber damage of Khumal Seto, PRP-056267.1 and IPY-8 were commonly found less damaged types in all the three separate data (Table1, Table2 and Table3). Similarly, the genotype NPI106 was found the moderately damaged type in the three separate data. The genotypes CIP-395112.32 and Cardinal were found highly damaged types in the two data (Table1 and Table3). The more or less similar results of the three data for the levels of tubers damage indicated that the formula/technique (developed by Sharma et al 2015) used in this study was approximately realistic and effective to screen damage levels of a large number of potato genotypes against red ant under natural infestation. Based on the TDI values of the combined data, the five genotypes Khumal Seto, PRP-056267.1, IPY-8, PRP25861.1, and Janak Dev were found less damaged types which possessed the TDI values in the range of 0.35 to 0.49 (Table 4). The six genotypes CIP-385499.11, Kufri Jyoti, PRP-226567.11, CIP-394050.110, PRP-85861.8, and NPI-106 were determined to be the moderately damaged types which possessed the TDI values in the range of 0.50 to 0.64 (Table 4). The three genotypes Desiree, CIP-395112.32, and Cardinal were determined to be the highly damaged types that possessed the TDI values in the range of 0.65 to 0.79 (Table 4 ).

\section{DISCUSSION}

The varietal damage of potato caused by red ant had studied in the past at Lumle, Bhitri, and Kabre in Nepal during 1995, 1996 and 1997 (Joshi 1998). The percent tuber damage of potato varieties Cardinal, Chisapani Rato, Kufri Jyoti, Sabet Local, Desiree, Khumbule, MS 42-3 including few other varieties were compared in the study. The local varieties Sabet local, Chisapani Rato and Khumbule were least damaged (15.5- 36.2\%, 22.4 - 39\% and 38.5 - 55\%) as compared to improved varieties Kufri Jyoti, Desiree and Cardinal that were moderately to highly damaged (43.8 - 61.8\%, $36.9-77 \%$ and 54.8 $70.6 \%$ ) by red ant, respectively. The study clearly showed that varietal response on tubers damage by red ant varied among variety to variety, the least damaged variety was Sabet local and heavily damaged varieties were Cardinal and Desiree. The variety of Kufri Jyoti was moderately damaged. The findings of the past studies were similar to the findings of the present study. As of the past findings, the tubers damage index values of test varieties of the present study were clearly varied due to the various responses of the test varieties to red ant attack (Tables 1, 2, 3,4). Likewise, as of the past study, the varieties Cardinal and Desiree were found highly damaged types and Kufri Jyoti was found moderately damaged type by a red ant in the present study (Table 4). In the past study (Joshi 1998), the variety MS 42-3 was found highly damaged (27 - 82.3\%) type but in a different study (Pandey and Dhital1995) the variety MS 42-3 was found less damaged $(<5 \%)$ type by red ant. In another study in the past (Joshi1998), reported that earlier identified red ant resistant variety CFM 69-1 was heavily attacked by red ant. The contradictory responses of MS 42-3 variety to red ant attack, and the severe attack by red ant to the resistant variety CFM 69-1, in the past studies, may be due to the differences in virulence of various strains of red ant in the study areas.

Utilization of host plant resistance is the best alternative to minimize crop losses caused by the pests. In a previous study, two different sets (25 genotypes in one set and 46 in another set) of potato genotypes were evaluated and compared for the levels of tubers damage against red ant (Sharma et al 2015). Among the two sets of potato genotypes, the two genotypes CIP-385499.11 and CIP-393077.54 were found the least damaged ones in the set of 25 genotypes, and the four genotypes PRP-056267.9, PRP-056267.1, CIP395112.32, and PRP-016567.12 were found the least damaged types in the set of 46 genotypes. In a different study, among the 20 potato genotypes compared for the level of tubers damage, the nine genotypes CIP-390663.8, CIP-395195.7, CIP-392820.1, CIP-393617.1, CIP-39461.139, Khumal-Uphar, CIP-399101.1, PRP-226567.2, and PRP-01567.1 were found the less damaged types against red ant (Sharma et al 2017). This study identified five genotypes IPY-8, Khumal Seto, PRP-056267.1, Janak Dev and PRP-25861.1 to be the less damaged types against a red ant. The less damaged potato genotypes identified in the present and past studies can be used by farmers as the relatively resistant genotypes against the red ant. 
In the recent past and present studies, a formula developed by Sharma et al (2015) was used to compare damage levels of a large number of potato genotypes under natural infestation of red ant in red ant sick field. The results of the studies clearly indicated that the formula used in the studies is proved to be a simple and effective technique to approximately categorize the damage levels of a large number of potato genotypes under natural infestation. Evaluation of damage levels of potato genotypes under artificial infestation requires mass production of red ant. Mass production of red ant was reported to be unfeasible (Joshi 1998). In such a context, the varietal screening of potato against red ant using the technique is reasonably and practically effective.

\section{ACKNOWLEDGMENTS}

Nepal Agricultural Research Council (NARC) is highly acknowledged for funding this research project.

\section{REFERENCES}

Alam SN. 2012. Entomological Research Abstracts. Entomology Division, Bangladesh Agricultural Research Institute, Joydebpur, Gazipur; p.282.

Bhandari MR. 2011. Assessment of red ant organic management options in potato field of Dhading, Nepal. Nepalese Journal of Agricultural Science 9; pp.90-94.

Joshi SL. 1998. Ecology and management of the red ant, Dorylus orientalis Westwood in Nepal.Doctoral Thesis. Imperical College of Science, Technology and Medicine, University of London; pp.193-201.

Konor A, S Paul, A Basu and M Chattri. 2005. Integrated management of mole cricket attacking potato in Eastern Gangetic Plains of West Bengal. Potato J.32:250.

Machida-Hirano R. 2015. Diversity of potato genetic resources. Breed. Sci. 65:26-40.

Mishra RK, SS Singh and L Singh. 1993. Incidence of red ant, Dorylus orientalis on different genotypes of potato. J. Indian Potato Assoc.20:62.

Pandey RR and BK Dhital .1995. Potato Insect Pests Records of LARC. National Winter Crops Workshop, 7-10 September 1995. Regional Agricultural Research Station, Bhairahawa, Nepal.

RARS.2011/12.Annual Report 2011/12. Regional Agricultural Research Station (RARS), Lumle.

Sharma PN and P Gautam. 2005. Resistance screening of maize germplasms against maize stem borer (Chilo partellus Swinhoe) in Nepal. In: Books of Abstracts. Ninth Asian Regional Maize Workshop (9th ARMW), 59 September 2005, Jointly organized by Chinese Academy of Agricultural Sciences (CAAS) and CIMMYT, Beijing, China; p.29.

Sharma PN, A Torii, S Takumi, N Mori and C Nakamura. 2004. Marker-assisted pyramiding of brown plant hopper (Nilaparvata lugens Stål) resistance genes Bphl and Bph2 on rice chromosome 12. Hereditas 140:61-69.

Sharma PN, BP Neupane, KP Upadhyay and BB Khatri. 2017. Varietal evaluation of potato (Solanum tuberosum L) for levels of tuber damage in field caused by red Ant (Dorylus orientalis Westwood). In: Proceedings of National Potato Working Group Workshop (KP Upadhyay and P Bhattarai, eds). 9-10 November 2017, NPRP, Khumaltar, Lalitpur, Nepal; pp.77-79.

Sharma PN, BP Sharma, BB Khatri, HP Pathak and D Chaudhari. 2015. Varietal screening of potato (Solanum tuberosum L.) against red ant (Dorylus orientalis Westwood). In: Proceedings of the $11^{\text {th }}$ National Outreach Research Division (D Bhandari and S Piya, eds). NARC, Khumaltar; pp.199-203.

Sharma PN, K Murata, A Torii, S Takumi, N Mori and C Nakamura. 2003b. Towards molecular cloning of resistance genes against brown plant hopper (Nilaparvata lugens Stål) in rice: A case study of natural insect resistance genes. Trends in Entomology 3:87-96.

Sharma PN, N Mori, S Takumi and C Nakamura. 2014.Conventional and molecular studies of brown plant hopper (Nilaparvata lugens Stål) resistance genes in rice: A basis for future study of natural insect resistance genes using molecular markers in Nepal. Nepal Journal of Science and Technology 15(1):145-156.

Sharma PN, RB Thapa, P Gautam and YP Giri. 2010. Screening of resistance for maize inbreds and hybrids against maize weevil (Sitophilus zeamais Motsch). In: Proceedings of the $9^{\text {th }}$ National Outreach Research Workshop, 7-8 June 2010 (24-25 Jestha 2067), NARC, Kathmandu; pp.196-200.

Sharma PN, RB Thapa, P Gautam and YP Giri. 2012. Resistance screening of stored grains of open pollinated promising maize genotypes against maize weevil (Sitophilus zea mais Motsch). In: Proceedings of $26^{\text {th }}$ National Summer Crops Research Workshop, 3-5 March 2010, Rampur, Chitwan, Nepal. Published by NARC, Singh Durbar Plaza, Kathmandu, Nepal; pp.392-396. 
Sharma PN, Y Ketipearachchi, K Murata, A Torii, S Takumi, N Mori and CNakamura. 2003a. RFLP/AFLP mapping of a brown plant hopper (Nilaparvata lugens Stål) resistance gene Bphl in rice. Euphytica 129:109117.

Sharma PN, YP Giri, GS Bhandari and P Thakur. 2012. Screening of resistance for stored grains of promising maize genotypes against maize weevil (Sitophilus zeamais Motsch). In: Proceedings of the 4th SAS-N Convention, 4-6 April 2012; pp.95-98.

Watanabe K. 2015. Potato genetics, genomics and applications. Breed Sci. 2015 Mar. 65(1):53-68.

$|1------1|------1 \mid$ 